\title{
SEBARAN SPL KAITANNYA DENGAN HASIL TANGKAPAN IKAN CAKALANG (KATSUWONUS PELAMIS) DI PERAIRAN ACEH
}

\author{
Distrbution Sea-Surface Temperature (Sst) Impect to Skipjack (Katsuwonus pelamis) \\ Catch in Aceh Waters \\ Oleh: \\ M. Habib EY1*, Nofrizal², Mubarak ${ }^{3}$
1Politeknik Kelautan dan Perikanan Dumai, Jl.Wan Amir, Kec.Dumai Barat, Riau. habib.tpi.47@gmail.com
2Universitas Riau, Kampus Bina Widya, Km 12,5, Simpang Panam, Pekanbaru.aan_fish@yahoo.com \\ 3Universitas Riau, Kampus Bina Widya, Km 12,5, Simpang Panam, Pekanbaru. mubarakhalim@yahoo.com \\ *Korespondensi: habib.tpi.47@gmail.com
}

Diterima: 21 Mei 2018; Disetujui: 18 Maret 2019

\begin{abstract}
Skipjack (Katsuwonus pelamis) has high economic value and many catched in Aceh waters. This study aims to calculate the catch of skipjack, compare the Sea-Surface Temperature (SST) on satellite image with real sea-surface temperature, and determine the effect of sea-surface temperature for the skipjack catch in Aceh waters. This study used data of skipjack catch, seasurface temperatureon satellite image and real sea-surface temperature (on field) that was conducted in September 2017, using survey method in 32 points of fishing ground with 3 trips. Average of sea-surface temperature was around $27.24^{\circ} \mathrm{C}$, while the sea-surface temperature in Aqua MODIS images was around $28.21{ }^{\circ} \mathrm{C}$ in the transition of east-west season. There was differences in real sea-surface temperature and image sea-surface temperature of satellite, but it is not significant. Total catch of skipjack fish in September 2017 was $51,409 \mathrm{~kg}$, and average of CPUE was $1,658 \mathrm{~kg} / \mathrm{setting}$. The highest catch of skipjack was $13,280 \mathrm{~kg}$ with sea-surface temperature at $27,4^{\circ} \mathrm{C}$ because that temperature is the optimum temperature for skipjack. Temperature is affects to the skipjack distribution.
\end{abstract}

Keywords: Katsuwonus pelamis, MODIS, SST

\section{ABSTRAK}

Ikan cakalang (Katsuwonus pelamis) merupakan salah satu jenis ikan yang mempunyai nilai ekonomis tinggi, dan banyak tertangkap di Perairan Aceh. Penelitian ini bertujuan untuk menghitung hasil tangkapan ikan cakalang, membandingkan antara SPL citra dan SPL di lapangan, dan untuk mengetahui pengaruh SPL terhadap hasil tangkapan ikan cakalang di Perairan Aceh, dengan menggunakan data hasil tangkapan ikan cakalang, SPL citra dan SPL lapangan. Penelitian dilakukan pada bulan September 2017. Metode yang digunakan adalah metode survei dengan 32 titik stasiun lokasi penangkapan dengan melakukan 3 trip pelayaran dengan rata-rata SPL lapangan sekitar $27,24^{\circ} \mathrm{C}$. Adapun SPL pada citra Aqua MODIS sekitar $28,21^{\circ} \mathrm{C}$ pada musim peralihan timur - barat. Walaupun terdapat perbedaan SPL lapangan dan citra tetapi tidak terlalu signifikan. Total hasil tangkapan ikan cakalang pada bulan September 2017 sebanyak 51,409 kg, dengan rata-rata CPUE 1,658 kg/setting. Hasil tangkapan ikan cakalang paling banyak tertangkap pada suhu $27,4^{\circ} \mathrm{C}$ sebanyak $13.280 \mathrm{~kg}$. Hal ini disebabkan pada suhu tersebut merupakan suhu optimum ikan cakalang karena suhu mempengaruhi distribusi penyebaran ikan.

Kata kunci: Katsuwonus pelamis, MODIS, SPL 


\section{PENDAHULUAN}

Perairan Aceh merupakan perairan yang memiliki potensi sumberdaya perikanan yang tinggi, jumlah penangkapan ikan di wilayah Perairan Aceh juga tinggi sehingga produksi penangkapan yang didaratkan di Pelabuhan Perikanan Samudera (PPS) Lampulo juga tinggi. Berdasarkan data yang diperoleh dari PPS Lampulo (2016), produksi perikanan pada tahun 2016 tercatat sebanyak $12.579 .921 \mathrm{~kg}$. Potensi sumberdaya perikanan tinggi di wilayah Perairan Aceh dikarenakan Perairan Aceh berbatasan langsung dengan Laut Andaman dan Samudera Hindia. Perairan tersebut sering dilalui ikan pelagis besar dan merupakan jalur ruaya ikan tersebut. Sehingga bisa meningkatkan perekonomian nelayan Aceh (Kurnia et al. 2016).

Ikan pelagis besar yang sering menjadi hasil tangkapan adalah ikan cakalang. Menurut data yang diperoleh dari PPS Lampulo (2016), jumlah hasil tangkapan cakalang pada tahun 2016 di PPS Lampulo sebanyak $4.451 .764 \mathrm{~kg}$. Kondisi penangkapan cakalang mengalami penurunan dari tahun ke tahun. Hal ini disebabkan karena perubahan cuaca/iklim yang sangat drastis, sehingga dalam menentukan daerah penangkapan ikan menjadi kurang efisien dan berdampak pada penurunan jumlah produksi perikanan khususnya produksi perikanan cakalang.

Cakalang merupakan ikan yang memiliki nilai ekonomis yang sangat tinggi dan hasil tangkapan cakalang berskala ekspor dimana biasanya hasil tangkapan cakalang ini diekspor ke berbagai negara, seperti : Jepang, Thailand dan Inggris. Ikan cakalang ini juga merupakan hasil tangkapan utama masyarakat sekitar Perairan Aceh. Sehingga masyarakat di wilayah perairan tersebut sangat bergantung pada banyak sedikitnya hasil tangkapan cakalang. Menurut Amir dan Mallawa (2015), cakalang merupakan ikan ekonomis tinggi. Hal ini juga sependapat dengan Prayoga et al. (2017), bahwa cakalang merupakan sumberdaya perikanan paling dominan dan mempunyai nilai ekonomis yang tinggi.

Pola kehidupan ikan tidak dapat dipisahkan dengan kondisi lingkungan. Fluktuasi keadaan lingkungan mempunyai pengaruh yang besar terhadap keberadaan ikan. Menurut Jufri et al. (2014), parameter yang sangat berkaitan dengan ikan adalah kondisi oseanografi, salah satunya SPL sangat berpengaruh terhadap metabolisme ikan secara biologis, dilihat dari pengaruh fisiknya, suhu permukaan dapat menyebabkan upwelling yang membawa nutrient ke permukaan dan menjadikan tempat feeding ground bagi ikan, sehingga parameter suhu dapat dijadikan indikator dalam penentuan keberadaan ikan. Menurut Blackburn (1965) dalam Talib (2017), ikan cakalang ditemukan di perairan bebas dengan SPL berkisar antara 27,0 $30,0^{\circ} \mathrm{C}$ dengan suhu optimum $20,0-28,0^{\circ} \mathrm{C}$.

Data citra satelit yang sekarang telah banyak digunakan untuk memprediksi daerah penangkapan ikan sudah banyak dilakukan dan digunakan oleh para peneliti, tetapi dikarenakan perubahan cuaca/iklim yang sangat drastis membuat data tersebut menjadi kurang akurat, sehingga perlu adanya kesesuaian antara data di lapangan dengan data citra satelit. Kesesuaian antara kedua data tersebut dapat dijadikan acuan bagi pelaku usaha penangkapan ikan untuk dapat menggunakan data citra satelit dalam memprediksi daerah panangkapan ikan cakalang, sehingga aktivitas penangkapan ikan lebih efektif. Menurut Aguslina et al. (2016), informasi keberadaan ikan merupakan salah satu kunci keberhasilan dalam pengembangan perikanan tangkap.

Oleh karena itu tujuan penelitian ini ialah untuk membandingkan SPL dari citra dan pengukuran langsung, menghitung hasil tangkapan ikan cakalang di lokasi penelitian, kemudian menghubungkan SPL dan hasil tangkapan.

\section{METODE}

Penelitian ini dilaksanakan pada bulan September 2017 di Perairan Aceh dengan koor-

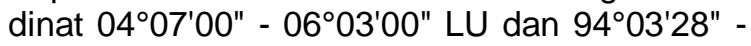
96 02'13" BT, Kota Banda Aceh (Gambar 1) di Pelabuhan Perikanan Samudera (PPS) Lampulo yang terletak di Muara Krueng Aceh dalam Kecamatan Kuta Alam Kota Banda Aceh.

Penelitian ini meliputi pengambilan data hasil tangkapan ikan cakalang, data sebaran SPL dari citra satelit dan SPL lapangan dengan pengukuran langsung (in-situ). Data SPL lapangan diambil menggunakan termometer pada saat setiap melakukan proses penangkapan, dengan cara meletakkan bagian thermometer sensor ke dalam laut pada saat menurunkan alat penangkap ikan. Kemudian melakukan pengambilan data hasil tangkapan per penangkapan, pada saat menaikkan alat penangkapan ikan langsung didata jumlah hasil tangkapan ikan cakalang dan dicatat berapa SPL lapangannya. Penelitian dilakukan menggunakan kapal nelayan selama satu bulan dengan melakukan tiga trip pelayaran di 32 titik lokasi penangkapan yang berbeda, di sekitar Selat Malaka, Sabang, Pulo Aceh dan Samudera Hindia pada Gambar 1. 


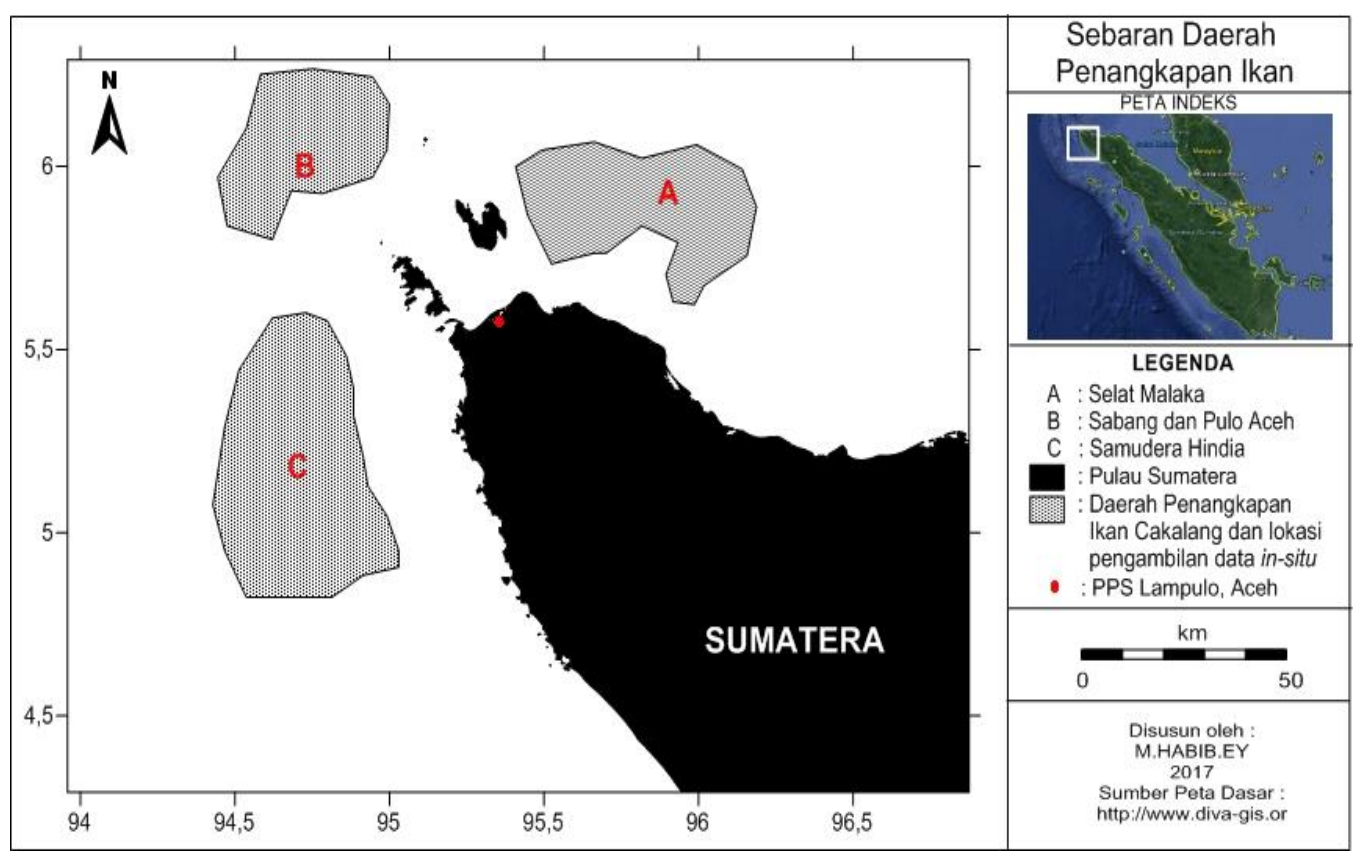

Gambar 1 Peta daerah penelitian

Penelitian ini juga menggunakan penginderaan jauh, menurut Putra et al. (2012), mengatakan penginderaan jauh merupakan teknik yang dapat diaplikasikan untuk pengamatan parameter oseanografi perairan seperti SPL baik secara spasial maupun temporal. Hal ini juga sependapat dengan Prastianto (2016), yang mengatakan bahwa penggunaan teknologi penginderaan jauh merupakan solusi terbaik dalam menentukan daerah penangkapan ikan. Pengambilan data SPL citra harian dilakukan satu kali dalam satu hari kemudian dioverlay menjadi data mingguan yang diperoleh dari http://oceancolour.gsfc.nasa.gov, dengan menyediakan foto citra pada saat siang dan malam hari. Proses pengoperasian penangkapan ikan sekaligus pengambilan data in-situ dilakukan mulai pukul 17.00 WIB - 06.00 WIB, maka data yang digunakan adalah data SPL citra harian pada saat malam hari.

Alat yang digunakan dalam penelitian ini meliputi komputer berbasis internet untuk mengakses web penyedia informasi oseanografi yang meliputi SPL, software SeaDas 7.4, ArcMap 10.2.2, Surfer 13 dan SPSS 21. Alat yang digunakan dilapangan meliputi Alarm Thermometer type AL - 2, Echo Sounder Furuno LS-6100, Global Positioning System Furuno GP - 32. Bahan yang digunakan adalah data harian citra MODIS Aqua/Terra level 3 bulan September 2017 dengan resolusi $4 \mathrm{~km} \times 4 \mathrm{~km}$, dan data sheet hasil tangkapan ikan.

Penelitian ini dilakukan dengan metode survei yaitu mengumpulkan data lapangan dengan melakukan pengamatan secara langsung. Kemudian dilakukan perbandingan antara data SPL lapangan dan SPL citra, SPL lapangan dan SPL citra menggunakan uji normalitas kolmogorof smirnov dengan SPSS 21, yang nantinya akan dioverlay menggunakan software Surfer 13 dengan hasil tangkapan ikan yang telah dikelompokkan berdasarkan lokasi dan jumlah hasil tangkapan per hari dan unit penangkapannya. Peta hasil overlay tersebut dapat disatukan dan akan terbentuk peta baru dengan spesifik informasi mengenai daerah penangkapan ikan yang produktif dan dikenal dengan zona optimum penangkapan ikan cakalang (Zainuddin et al. 2013). Selanjutnya nilai hasil tangkapan dihitung per upaya penangkapan CPUE(Catch Per Unit Effort).

Formula yang digunakan untuk mengetahui nilai CPUE adalah sebagai berikut:

CPUE $_{i}=\frac{\text { catch }_{i}}{\text { effort }_{i}}$

$\mathrm{i}=1,2,3 \ldots, \mathrm{n}$

dengan $C P U E_{i}$ merupakan hasil tangkapan perupaya penangkapan (kg/trip) dalam minggu, catch $_{i}$ merupakan hasil tangkapan $(\mathrm{kg})$ dalam minggu ke-i, dan effort $t_{i}$ ialah upaya penangkapan (trip) dalam minggu ke-i.

\section{HASIL}

\section{Waktu Operasi Penangkapan dan Hasil Tangkapan}

Pelaksanaan operasi penangkapan ikan cakalang di Perairan Aceh dilakukan sebanyak tiga trip/bulan dengan melakukan sebanyak 31 kali setting pada lokasi yang berbeda, lamanya 
waktu operasi penangkapan adalah 6-7 hari/trip dengan membutuhkan waktu 3-4 jam/ setting.

Pengambilan data hasil tangkapan didapat langsung di lapangan dengan mengikuti proses penangkapan ikan bersama nelayan. Pada saat melakukan penangkapan harus memperhatikan selektifitas alat tangkap. Menurut Triarso (2012), dengan minimnya selektifitas alat tangkap akan terjadinya over fishing di Perairan Indonesia. Sependapat dengan Rambun et al. (2016), alat tangkap dengan tingkat selektifitas yang tinggi akan membuat kelangsungan sumberdaya akan terjaga.

Total hasil tangkapan ikan cakalang di Perairan Aceh selama melaksanakan penelitian adalah sebanyak $51.409 \mathrm{~kg}$ dengan rata-rata CPUE 1.658 kg/setting, dengan Fork length maksimum ikan cakalang dapat mencapai hingga $108 \mathrm{~cm}$ dengan berat 32,5 - 34,5 kg dengan ukuran yang umum tertangkap $40-80 \mathrm{~cm}$ dengan berat 8 - $10 \mathrm{~kg}$. Hal ini juga sependapat dengan Vinh (2000) dalam Hallier dan Gaertner (2006), yang menduga ukuran ikan cakalang di Laut Cina sebesar 28, 42, dan $50 \mathrm{~cm}$ dengan umur 1, 2, dan 3 tahun.

Hasil tangkapan yang sudah dinaikkan ke atas kapal langsung dilakukan penanganan agar kualitas ikan tetap terjaga karena menurut Nurani et al. (2013), masalah yang sering dialami pada pasar ekspor Indonesia adalah kasus penolakan produk ikan oleh FDA (Food and Drug Administration) yang disebabkan kandungan bakteri atau kadar histamin yang tinggi karena penanganan produk yang kurang baik. Sebaiknya produk ditangani dengan cepat dan langsung dimasukkan ke dalam palka. Menurut Sahidi et al. (2015), makin banyak permukaan ikan yang bersinggungan dengan es, maka pendinginan akan berlangsung lebih cepat sehingga pembusukan dapat segera dihambat. Hasil tangkapan ikan cakalang per trip penangkapan pada Tabel 1.

\section{SPL dan Hasil Tangkapan}

Pada saat melakukan penelitian bulan September 2017 bertepatan dengan akhir musim timur dan awal musim peralihan timur - barat, rata-rata SPL sekitar $28,79{ }^{\circ} \mathrm{C}$, pada citra bulan September 2017 variasi SPL berkisar antara 25 - $30{ }^{\circ} \mathrm{C}$. SPL minimum $25,46{ }^{\circ} \mathrm{C}$ terdapat di sebelah barat daya Aceh sedangkan SPL maksimum $29,95{ }^{\circ} \mathrm{C}$ terdapat di sebelah barat Aceh dan sebelah timur laut Pulau Sabang. Data citra SPL pada bulan September 2017 bisa dilihat pada Gambar 2.

Tabel 1 Rekapitulasi hasil tangkapan ikan cakalang per trip penangkapan

\begin{tabular}{|c|c|c|c|c|c|c|c|}
\hline No & $\begin{array}{l}\text { Trip } \\
\text { ke }\end{array}$ & Tanggal & $\begin{array}{l}\text { Jumlah } \\
\text { Setting }\end{array}$ & $\begin{array}{l}\text { Hasil tangkapan } \\
(\mathbf{k g})\end{array}$ & $\begin{array}{l}\text { Hasil tangkapan } \\
\text { (Ekor) }\end{array}$ & $\begin{array}{c}\text { CPUE } \\
\text { (kg/setting) }\end{array}$ & $\begin{array}{l}\text { Fishing } \\
\text { Ground } \\
\text { (WPP RI) }\end{array}$ \\
\hline 1 & I & $6-13$ & 11 & 12.394 & 3.889 & 1.126 & 572 \\
\hline 2 & II & $14-21$ & 8 & 5.680 & 1.973 & 710 & 571 \\
\hline 3 & III & $22-29$ & 12 & 33.335 & 10.506 & 2.777 & 572 \\
\hline \multicolumn{3}{|c|}{ Total } & 31 & 51.409 & 16.368 & & \\
\hline
\end{tabular}

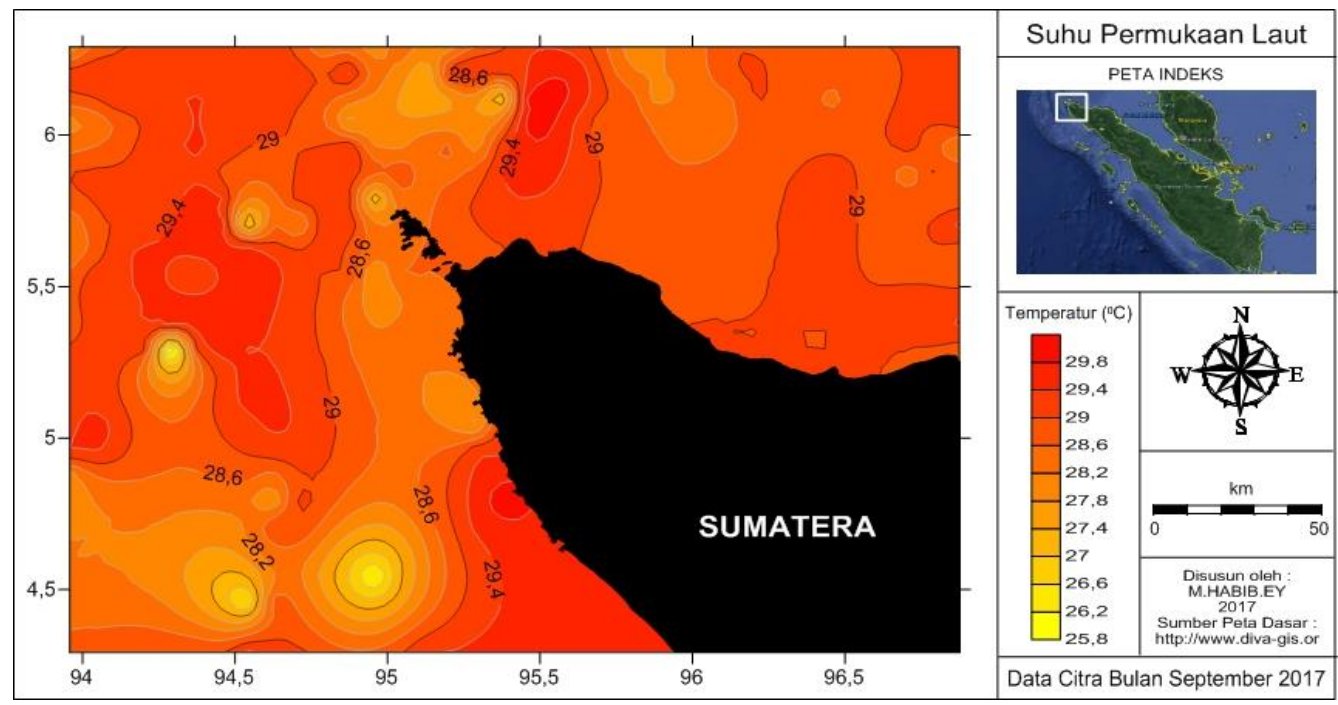

Gambar 2 Suhu permukaan laut (SPL) pada bulan September 2017 
Tabel 2 Hasil tangkapan ikan cakalang terbanyak berdasarkan rata-rata SPL per trip penangkapan

\begin{tabular}{cccccc}
\hline No & $\begin{array}{c}\text { Trip } \\
\text { ke }\end{array}$ & $\begin{array}{c}\text { Rata - rata } \\
\text { SPL }\left({ }^{\circ} \mathbf{C}\right)\end{array}$ & $\begin{array}{c}\text { Hasil tangkapan } \\
(\mathbf{k g})\end{array}$ & $\begin{array}{c}\text { Total hasil tangkapan } \\
(\mathbf{k g})\end{array}$ & $\begin{array}{c}\text { Fishing Ground } \\
\text { (WPP RI) }\end{array}$ \\
\hline 1 & I & 26,4 & 5,780 & 12.394 & 572 \\
2 & II & 27,6 & 2.050 & 5.680 & 571 \\
3 & III & 27,4 & 13.280 & 33.335 & 572 \\
\hline
\end{tabular}

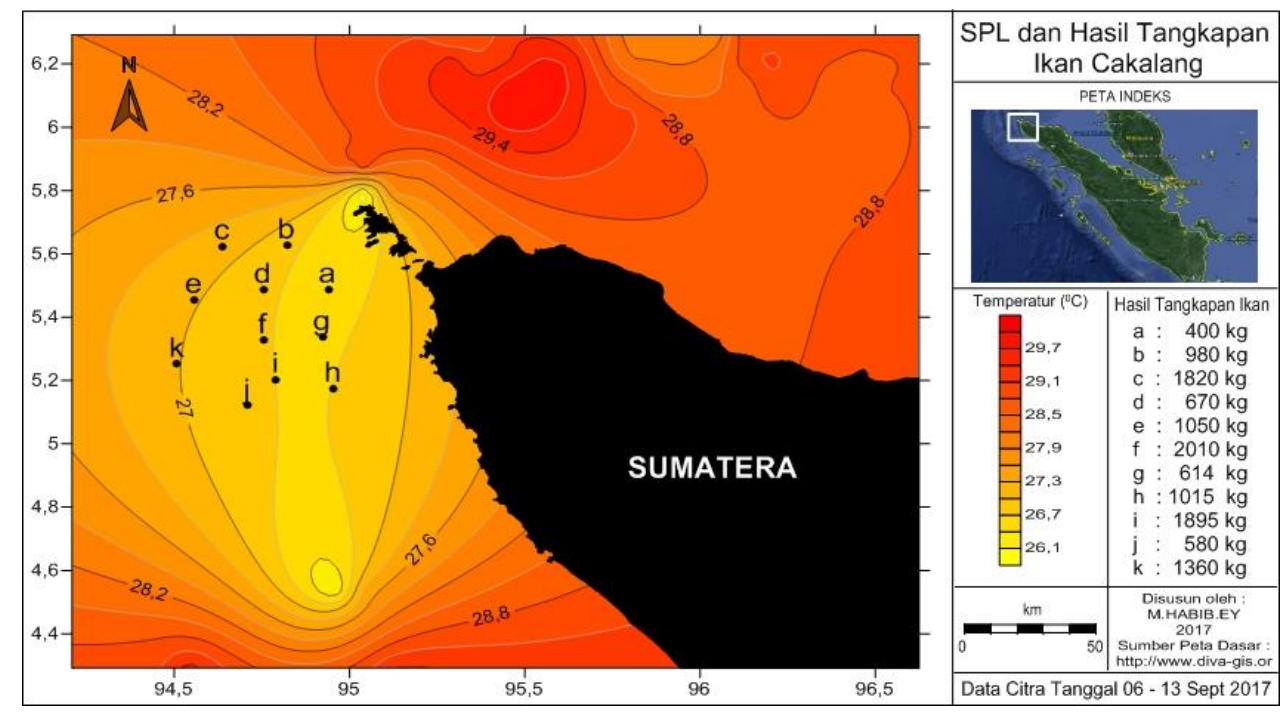

Gambar 3 Suhu permukaan laut (SPL) pada tanggal 6-13 September 2017

Keberadaan ikan cakalang salah satunya bisa ditentukan dengan mendeteksi SPL. Dari hasil penelitian didapat hasil tangkapan tertinggi pada setiap trip penangkapan berada pada suhu optimum keberadaan ikan cakalang, pada trip pertama hasil tangkapan terbanyak pada rata-rata SPL $26,4^{\circ} \mathrm{C}$ sebanyak $5.780 \mathrm{~kg}$ atau sekitar $32 \%$ dari total hasil tangkapan trip pertama, trip kedua hasil tangkapan terbanyak pada rata-rata SPL $27,6^{\circ} \mathrm{C}$ sebanyak $2.050 \mathrm{~kg}$ atau sekitar $27 \%$ dari total hasil tangkapan trip kedua, trip ketiga hasil tangkapan terbanyak pada rata-rata SPL $27,4^{\circ} \mathrm{C}$ sebanyak $13.280 \mathrm{~kg}$ atau sekitar $28 \%$ dari total hasil tangkapan trip ketiga. Hasil tangkapan per SPL pada setiap trip disajikan pada Gambar 3, 5, dan 7. Tabel hasil tangkapan terbanyak per SPL dan total hasil tangkapan per trip bisa dilihat pada Tabel 2.

Pemilihan waktu akuisisi citra 8 harian dengan kualitas citra yang baik, dengan mengambil 3 waktu yakni tanggal 6 - 13, 14 21 dan 22 - 29 September 2017. Pada waktu tersebut bertepatan dengan pengambilan SPL lapangan dan proses penangkapan ikan di Perairan Aceh.

\section{SPL Tanggal 6 - 13 September 2017}

Pada citra tanggal 6 - 13 September 2017, rata-rata SPL sekitar $28,83^{\circ} \mathrm{C}$. SPL minimum $25,82{ }^{\circ} \mathrm{C}$ terdapat di sebelah barat Pulau Sabang sedangkan SPL maksimum 29,94 ${ }^{\circ} \mathrm{C}$ terdapat di sebelah utara Pulau Sabang. Data citra SPL pada tanggal 6 - 13 September 2017 seperti pada Gambar 3.

Hasil tangkapan trip pertama dengan jumlah setting sebanyak sebelas kali pada koordinat yang berbeda dengan hasil tangkapan yang paling dominan pada SPL $26,4^{\circ} \mathrm{C}$ sebanyak $5.780 \mathrm{~kg}$, dan hasil tangkapan paling rendah pada SPL $27,2{ }^{\circ} \mathrm{C}$ sebanyak $400 \mathrm{~kg}$ dengan total hasil tangkapan ikan cakalang trip pertama sebanyak $12.394 \mathrm{~kg}$, dengan rata-rata CPUE $1.126 \mathrm{~kg} /$ setting. Grafik hasil tangkapan berdasarkan SPL lapangan tanggal 6 - 13 September 2017 seperti pada Gambar 4.

Ukuran ikan cakalang yang tertangkap pada saat melakukan penelitian pada trip pertama hanya $4 \%$ yang tidak layak tangkap, sisanya $96 \%$ merupakan ikan yang layak tangkap. Rata - rata ukuran fork length ikan cakalang yang tertangkap pada trip pertama yaitu $54 \mathrm{~cm}$.

\section{SPL Tanggal 14 - 21 September 2017}

Pada citra tanggal $14-21$ September 2017 rata-rata SPL sekitar $29,11^{\circ} \mathrm{C}$, SPL minimum $27,59{ }^{\circ} \mathrm{C}$ terdapat di sebelah utara dan barat daya Pulau Sabang sedangkan SPL maksimum $29,99{ }^{\circ} \mathrm{C}$ terdapat di sebelah barat dan barat laut Pulau Sabang. Data citra SPL tanggal 14 - 21 September 2017 seperti pada Gambar 5. 


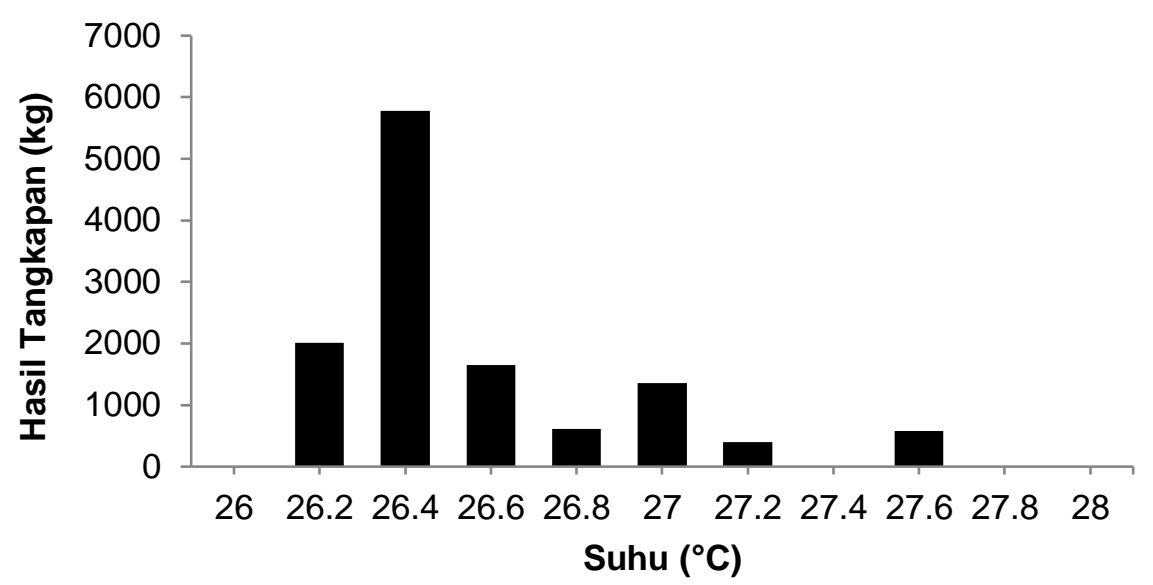

Gambar 4 Hasil tangkapan berdasarkan SPL lapangan 6 - 13 September 2017

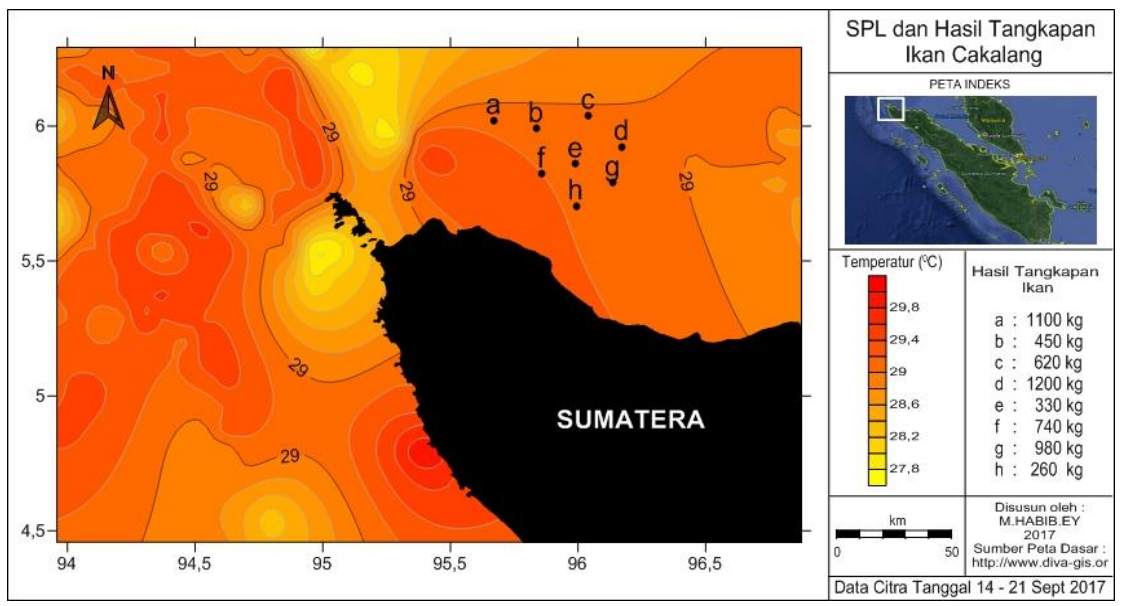

Gambar 5 Suhu permukaan laut (SPL) pada tanggal 14-21 September 2017

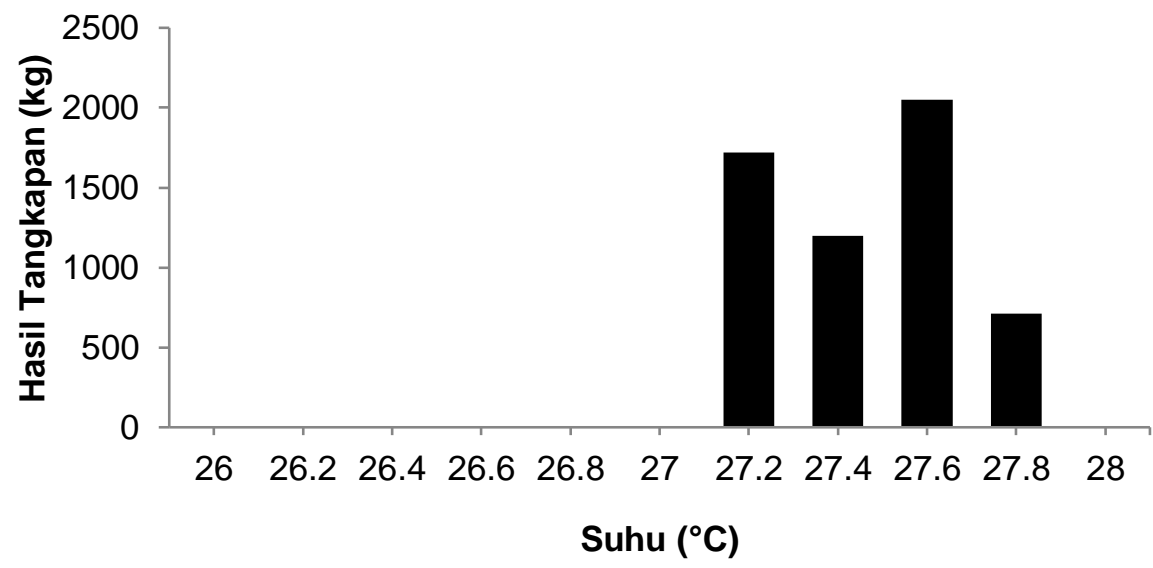

Gambar 6 Hasil tangkapan berdasarkan SPL lapangan 14-21 September 2017

Grafik hasil tangkapan berdasarkan SPL lapangan tanggal 14 - 21 September 2017 seperti pada Gambar 6 .

Hasil tangkapan trip kedua dengan jumlah setting sebanyak delapan kali pada koordinat yang berbeda dengan hasil tangkapan yang paling dominan pada SPL $27,6^{\circ} \mathrm{C}$ sebanyak $2.050 \mathrm{~kg}$. Hasil tangkapan paling rendah pada SPL $27,8{ }^{\circ} \mathrm{C}$ sebanyak $710 \mathrm{~kg}$, total hasil tang- kapan ikan cakalang trip kedua sebanyak 5.680 $\mathrm{kg}$, dengan rata-rata CPUE $710 \mathrm{~kg} / \mathrm{setting}$.

Ukuran ikan cakalang yang tertangkap pada saat melakukan penelitian pada trip pertama hanya $23 \%$ yang tidak layak tangkap, sisanya $77 \%$ merupakan ikan yang layak tangkap, rata - rata ukuran fork length yang tertangkap pada trip kedua $53 \mathrm{~cm}$. 


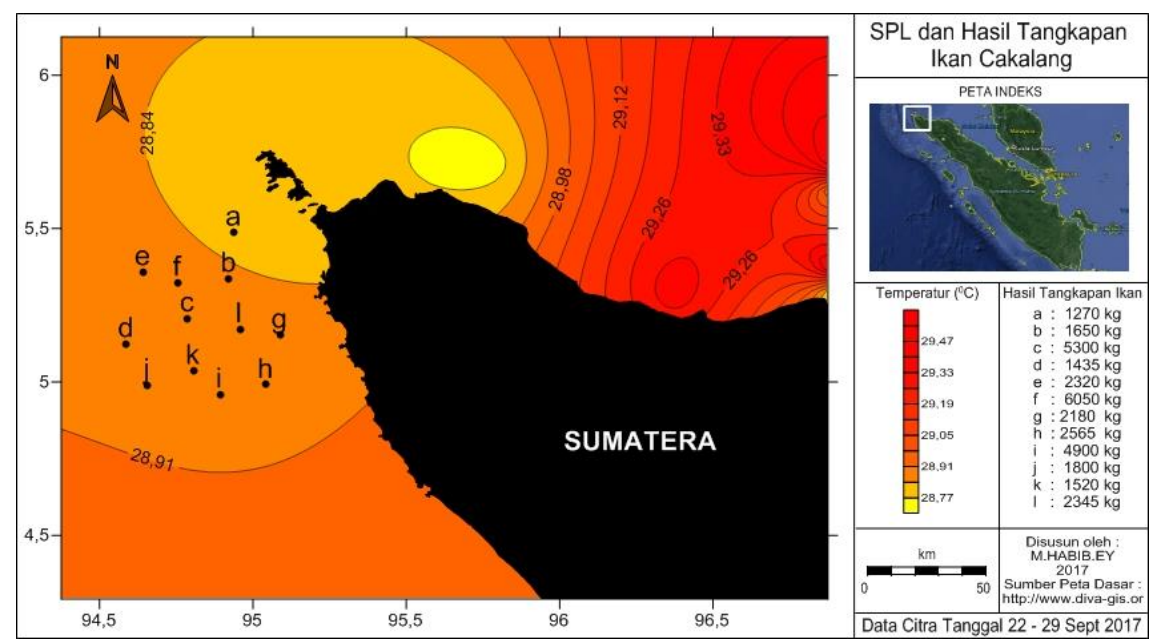

Gambar 7 Suhu permukaan laut (SPL) pada tanggal 22-29 September 2017

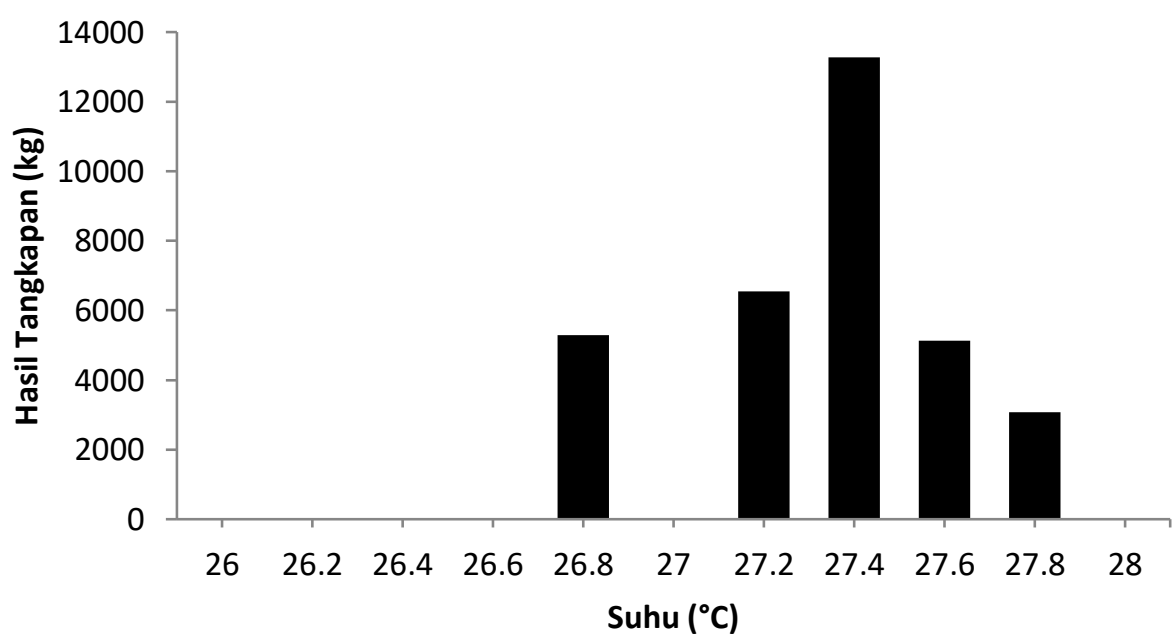

Gambar 8 Hasil tangkapan berdasarkan SPL lapangan 22-29 September 2017

\section{SPL Tanggal 22 - 29 September 2017}

Pada citra tanggal 22 - 29 September 2017 rata-rata SPL sekitar $29,11^{\circ} \mathrm{C}$, SPL minimum $28,38{ }^{\circ} \mathrm{C}$ terdapat di sebelah timur laut Aceh sedangkan SPL maksimum $29,58^{\circ} \mathrm{C}$ terdapat di sebelah timur Pulau Sabang. Data citra SPL tanggal 22 - 29 September 2017 seperti pada Gambar 7.

Hasil tangkapan trip ketiga dengan jumlah setting sebanyak dua belas kali pada koordinat yang berbeda dengan hasil tangkapan yang paling dominan pada SPL $27,4{ }^{\circ} \mathrm{C}$ sebanyak $13.280 \mathrm{~kg}$. Hasil tangkapan terendah pada SPL $27,8{ }^{\circ} \mathrm{C}$ sebanyak $3.070 \mathrm{~kg}$. Total hasil tangkapan ikan cakalang trip ketiga sebanyak $33.335 \mathrm{~kg}$, dengan rata-rata CPUE 2.777 $\mathrm{kg} /$ setting. Gambar 8 merupakan grafik hasil tangkapan berdasarkan SPL lapangan tanggal 22 - 29 September 2017.

Ukuran ikan cakalang yang tertangkap pada saat melakukan penelitian pada trip per- tama hanya $5 \%$ yang tidak layak tangkap, sisanya $95 \%$ merupakan ikan yang layak tangkap, rata - rata ukuran fork length ikan cakalang yang tertangkap pada trip kedua $56 \mathrm{~cm}$.

\section{PEMBAHASAN}

\section{SPL dan Hasil Tangkapan}

Hasil tangkapan tertinggi terdapat pada trip ketiga sebanyak $33.335 \mathrm{~kg}$, banyaknya hasil tangkapan pada trip ketiga dibandingkan trip pertama dan kedua karena sudah normalnya beberapa faktor oseanografi pada akhir bulan di perairan tersebut. Perubahan SPL tersebut disebabkan karena adanya musim peralihan timur - barat di Perairan Aceh sehingga hasil tangkapan bulan September menyebabkan terjadinya fluktuasi yang tidak terlalu berbeda jauh dilihat pada Tabel 1.

Pada saat melakukan penangkapan ikan, hasil tangkapan yang menunjukkan produktivi- 
tas yang tinggi dominan berada jauh dari garis pantai yaitu di Samudera Hindia dan di Selat Malaka. Hasil ini sejalan dengan behaviour ikan cakalang yang menyenangi arus dan kedalaman perairan, dan penyebarannya di perairan tropis sangat dipengaruhi oleh lapisan termoklin (Laevastu dan Hela, 1970). Kedalaman renang ikan cakalang bervariasi tergantung jenisnya. Pada umumnya ikan cakalang dapat tertangkap di kedalaman 0 - 40 meter, di atas lapisan termoklin (Laevastu dan Hela, 1970). Ada beberapa faktor yang mempengaruhi ketebalan lapisan termoklin ini seperti: pertukaran bahan, percampuran massa air oleh gelombang, pergerakan massa air secara mendatar dan gelombang dalam (Hela dan Laevestu, 1970).

Pada awal musim peralihan timur - barat terlihat sebaran SPL disebagian besar Perairan Aceh memiliki SPL yang lebih dingin. Hal ini disebabkan pada musim peralihan timur - barat kemungkinan disebabkan oleh curah hujan yang tinggi, sehingga pemanasan matahari tidak efektif untuk meningkatkan SPL. Pada musim peralihan timur - barat September, Oktober dan November 2017 ditemukan fluktuasi suhu yang drastis seperti dari bulan September ke Oktober. Perubahan SPL yang drastis tersebut tidak membuat suhu optimum keberadaan ikan cakalang menjadi berubah, namum ikan cakalang tetap banyak tertangkap pada suhu optimumnya. Menurut Blackburn (1965) dalam Talib (2017), hal tersebut terjadi karena suhu optimumnya berkisar antara $27,0-30,0^{\circ} \mathrm{C}$.

\section{SPL Tanggal 6 - 13 September 2017}

Perbedaan SPL citra dan lapangan pada tanggal 6 - 13 September 2017 setelah dilakukan uji normalitas kolmogorof smirnov dengan menggunakan SPSS diketahui nilai sig untuk SPL adalah 0,963 > 0,05, yang menunjukkan bahwa SPL lapangan dan SPL citra terdistribusi normal. Selanjutnya perlu membuat grafik untuk melihat perbedaan antara SPL lapangan dan SPL citra. Jika titik keberadaan SPL berada dekat dari garis menunjukkan bahwa tidak terjadi perbedaan yang drastis dari kedua SPL, tetapi apabila menjauh dari garis maka terjadi perbedaan yang sangat drastis antara SPL lapangan dan SPL citra.

Gambar 9 memperlihatkan bahwa SPL citra lebih tinggi dibandingkan SPL yang diambil langsung di lapangan, tetapi tidak terlalu berbe$\mathrm{da}$, dan masih menunjukkan hubungan yang positif. Dari hubungan ini dijelaskan bahwa sebagian besar SPL di lapangan dapat dijelaskan oleh citra. Gambar 9 menunjukkan perbedaan SPL lapangan dan hasil pengolahan citra, yang merupakan grafik perbandingkan antara data SPL lapangan trip pertama dan hasil pengolahan citra pada 6 - 13 September 2017.

Hasil tangkapan pada trip pertama yang termasuk awal musim timur - barat masih terdapat tingkat klorofil-a yang tinggi. Menurut Putra et al. (2017), tingkat klorofil-a yang tinggi tersebut diduga karena terjadinya upwelling di

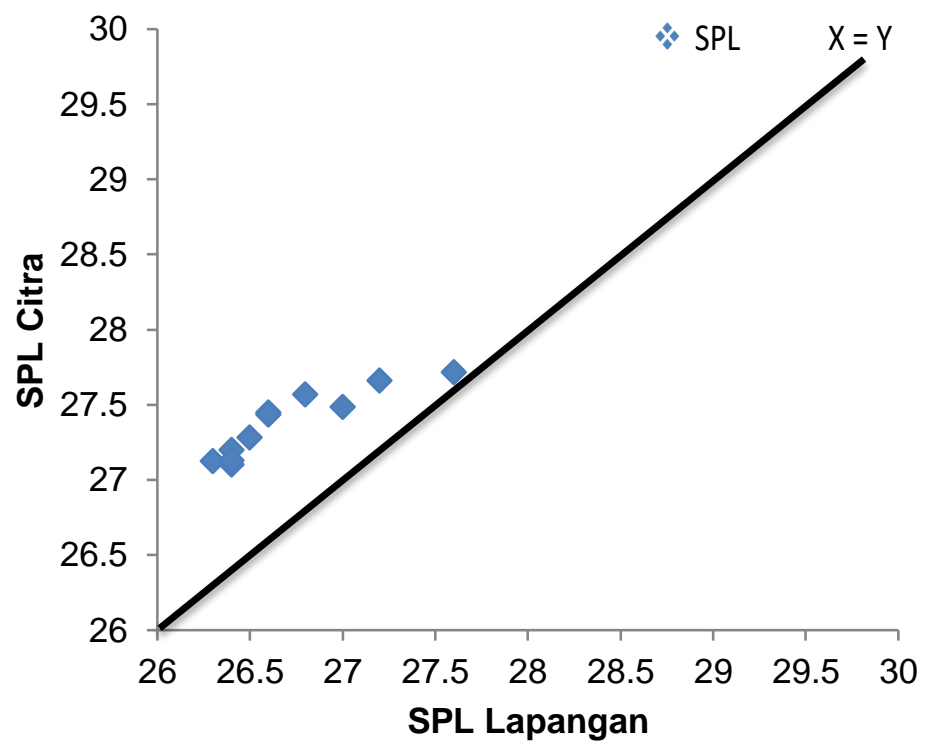

Gambar 9 Grafik perbandingan antara SPL lapangan dan SPL citra trip satu 


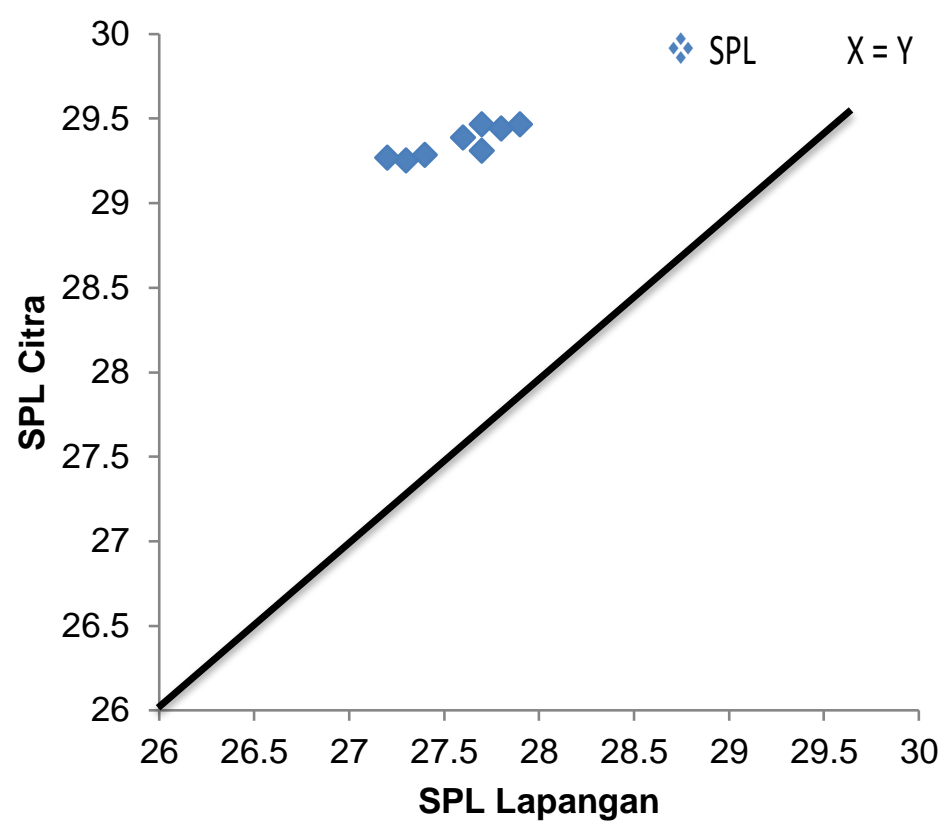

Gambar 10 Grafik perbandingan antara SPL lapangan dan SPL citra trip dua

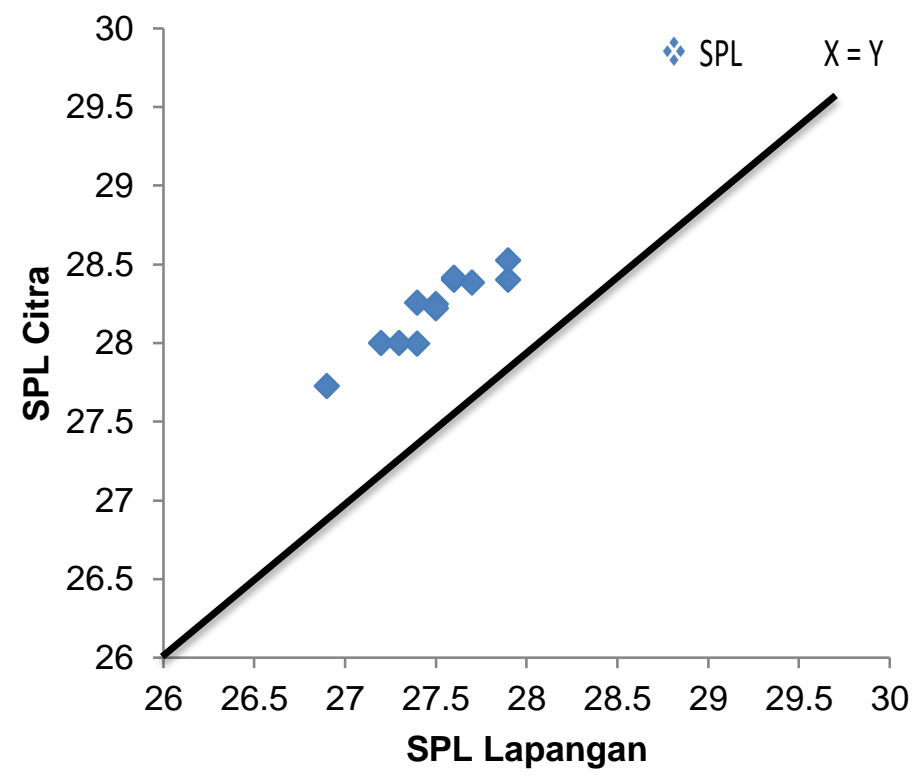

Gambar 11 Grafik perbandingan antara SPL lapangan dan SPL citra trip tiga

beberapa daerah di Indonesia sehingga tingkat klorofil-a masih tinggi dan dengan masuknya musim peralihan timur - barat terjadilah musim penghujan sehingga SPL menjadi lebih rendah yang menyebabkan hasil tangkapan ikan pada trip pertama banyak tertangkap pada suhu yang rendah $26,4^{\circ} \mathrm{C}$ sebanyak $5.780 \mathrm{~kg}$. Hasil tangkapan yang tinggi pada musim timur dan musim peralihan timur - barat sejalan dengan penelitian Kuswanto et al. (2017), yang mengatakan setiap tahun produksi pada musim timur atau musim peralihan dua selalu lebih besar dibandingkan musim yang lain. Hal ini juga sejalan dengan Hariati et al. (2010), yang menyatakan bahwa tingginya hasil tangkapan pada musim timur dan peralihan dua disebabkan oleh kandungan klorofil-a yang tinggi setelah proses upwelling.

\section{SPL Tanggal 14-21 September 2017}

Perbedaan SPL citra dan lapangan pada tanggal 14-21 September 2017 setelah dilakukan uji normalitas kolmogorof smirnov dengan menggunakan SPSS diketahui nilai sig untuk SPL adalah $0,892>0,05$, yang menunjukkan bahwa SPL lapangan dan SPL citra berdistribusi normal. Selanjutnya perlu membuat 
grafik untuk melihat perbedaan antara SPL lapangan dan citra. Jika titik keberadaan SPL berada dekat dari garis menunjukkan tidak terjadi perbedaan yang drastis dari kedua SPL. Akan tetapi apabila menjauh dari garis maka terjadi perbedaan yang sangat drastis antara SPL lapangan dan SPL citra.

Gambar 10 memperlihatkan bahwa SPL citra lebih tinggi dibandingkan SPL yang diambil langsung di lapangan tetapi tidak terlalu berbe$\mathrm{da}$, dan masih menunjukkan hubungan yang positif. Dari hubungan ini dijelaskan bahwa sebagian besar SPL di lapangan dapat dijelaskan oleh citra. Gambar 10 menunjukkan perbedaan SPL lapangan dan hasil pengolahan citra, yang merupakan grafik perbandingkan antara data SPL lapangan trip pertama dan hasil pengolahan citra pada 14 - 21 September 2017.

Hasil tangkapan pada trip kedua termasuk musim timur-barat yang mencirikan mu-sim penghujan sehingga SPL menjadi lebih me-rata di beberapa Perairan Aceh yang menye-babkan hasil tangkapan ikan pada trip kedua banyak tertangkap pada suhu yang lebih tinggi dari pada trip pertama. Menurut Blackburn (1965) dalam Talib (2017), bahwa ikan caka-lang ditemukan di perairan bebas dengan SPL berkisar antara $27,0-30,0{ }^{\circ} \mathrm{C}$ dengan suhu optimum $20,0-28,0^{\circ} \mathrm{C}$. SPL dapat digunakan sebagai salah satu cara untuk menduga keberadaan organisme di suatu perairan, khususnya ikan. Hal ini karena sebagian besar organisme bersifat poikilotermal. Tinggi rendahnya SPL pada suatu perairan terutama dipengaruhi oleh radiasi matahari. Menurut Hela dan Laevestu (1970) dalam Tangke et al. (2015), perubahan intensitas cahaya akan mengakibatkan terjadinya perubahan suhu air laut baik secara horizontal, mingguan, bulanan maupun tahunan.

\section{SPL Tanggal 22-29 September 2017}

Perbedaan SPL citra dan lapangan pada tanggal 22 - 29 September 2017 setelah dilakukan uji normalitas kolmogorof smirnov dengan menggunakan SPSS diketahui nilai sig untuk SPL adalah 0,971 >0,05, yang menunjukkan bahwa SPL lapangan dan SPL citra berdistribusi normal. Selanjutnya perlu membuat grafik untuk melihat perbedaan antara SPL lapangan dan SPL citra. Jika titik keberadaan SPL berada dekat dari garis menunjukkan bahwa tidak terjadi perbedaan yang drastis dari kedua SPL, tetapi apabila menjauh dari garis maka terjadi perbedaan yang sangat drastis antara SPL lapangan dan SPL citra.

Gambar 11 memperlihatkan bahwa SPL citra lebih tinggi dibandingkan SPL yang diambil langsung di lapangan, tetapi tidak terlalu berbe- da, dan masih menunjukkan hubungan yang positif. Dari hubungan ini dijelaskan bahwa sebagian besar SPL di lapangan dapat dijelaskan oleh citra. Gambar 11 menunjukkan perbedaan SPL lapangan dan hasil pengolahan citra, yang merupakan grafik perbandingan antara data SPL lapangan trip ketiga dan hasil pengolahan citra pada 22 - 29 September 2017.

Hasil tangkapan pada trip ketiga hampir sama dengan trip kedua karena termasuk musim timur-barat yang mencirikan musim penghujan. Kondisi ini mengakibatkan SPL menjadi lebih merata di beberapa Perairan Aceh yang menyebabkan hasil tangkapan ikan pada trip ketiga banyak tertangkap pada suhu yang lebih tinggi dari pada trip pertama. Menurut Blackburn (1965) dalam Talib (2017), ikan cakalang ditemukan di perairan bebas dengan SPL berkisar antara 27,0 - 30,0 ${ }^{\circ} \mathrm{C}$ dengan suhu optimum $20,0-28,0^{\circ} \mathrm{C}$. Hal ini juga sejalan dengan Jufri et al. (2014), yang menyatakan distribusi ikan cakalang dipengaruhi oleh kondisi oseanografi secara spasial maupun temporal.

\section{KESIMPULAN}

SPL di Perairan Aceh tidak terjadi fluktuasi yang terlalu jauh berbeda. Data SPL citra menunjukkan lebih tinggi dari pada SPL lapangan, disebabkan luasan sapuan sensor MODIS yang besar mengakibatkan kisaran SPL yang didapat masih dalam daerah yang luas (resolusi rendah). Namun perbedaannya tidak terlalu signifikan dengan SPL lapangan dan masih terdistribusi normal setelah dilakukan uji normalitas kolmogorof smirnov dengan menggunakan SPSS.

SPL sangat mempengaruhi hasil tangkapan ikan cakalang, Pada awal musim masih terdapat tingkat klorofil-a yang tinggi karena pengaruh adanya upwelling dan dengan masuknya musim peralihan timur - barat terjadilah musim penghujan sehingga SPL menjadi lebih rendah dan menyebabkan hasil tangkapan ikan pada trip pertama banyak tertangkap pada suhu yang rendah. Walaupun terjadi perubahan SPL pada awal musim peralihan timur - barat, ikan cakalang tetap banyak tertangkap di suhu optimumnya. Hal ini dibuktikan dengan banyak tertangkapnya ikan cakalang pada semua trip yang mendekati suhu optimumnya, trip pertama SPL $26,4{ }^{\circ} \mathrm{C}$ sebanyak $5.780 \mathrm{~kg}$, sedangkan pada trip ketiga paling banyak tertangkap pada suhu $27,4^{\circ} \mathrm{C}$ sebanyak $13.280 \mathrm{~kg}$, dengan total hasil tangkapan selama penelitian sebanyak $51.409 \mathrm{~kg}$ dengan rata-rata CPUE 1.658 $\mathrm{kg} /$ setting. 


\section{SARAN}

Perlu adanya penelitian lanjutan tentang penyebab pengaruh sebaran keberadaan ikan cakalang terhadap data SPL lapangan dan SPL citra, dan kajian tentang aktivitas biologi ikan cakalang di Perairan Aceh untuk mengetahui lebih jelasnya suhu optimum keberadaan ikan cakalang.

\section{UCAPAN TERIMA KASIH}

Penulis mengucapkan terimakasih yang sebesar - besarnya kepada keluarga besar Politeknik Kelautan dan Perikanan Dumai, Universitas Riau, Kepala Dinas Kelautan dan Perikanan Provinsi Aceh, Pimpinan Pelabuhan Perikanan Samudera Lampulo Provinsi Aceh, Alumni AUPSTP Provinsi Aceh. seluruh nelayan Provinsi Aceh yang telah membantu dan mendukung berjalannya penelitian ini dan semua pihak yang telah membantu dalam penelitian ini.

\section{DAFTAR PUSTAKA}

Aguslina SE, Tadjuddah M, Mustafa A. 2016. Sebaran Suhu Permukaan Laut dan Tracking daerah penangkapaan ikan $\mathrm{Ca}$ kalang di Perairan Laut Banda. Universitas Halu Oleo - Kendari. Jurnal Manajemen Sumber Daya Perairan. 2(1): 41-49.

Amir F, Mallawa A. 2015. Pengkajian Stok lkan Cakalang (Katsuwonus pelamis) Di Perairan Selat Makasar. Fakultas IImu Kelautan dan Perikanan. Universitas Hasanuddin - Makasar. Jurnal IPTEK PSP. 2(3): 208-217.

Hallier JP, Gaertner D. 2006. Estimated Growth Rate of the Skipjack Tuna (Katsuwonus pelamis) Tagging Survey Conducted in the Senegalese Area (1996-1999) Within a Meta-Analysis Franwork. Jurnal Col. Sci. Pap. ICCAT, 59(2): 411-420.

Hariati T, Amri K, Choridjah U. 2010. Fluktuasi Hasil Tangkapan Ikan Layang (Decapterus Spp) di Perairan Kendari dan Sekitarnya Serta Kaitannya Dengan Sebaran Suhu Permukaan Laut, Salinitas, dan Klorofil-a Permukaan. Badan Riset dan Sumber Daya Manusia Kelautan dan Perikanan. Jurnal Penelitian Perikanan Indonesia. 16(2).

Hela I, Laevastu T. 1970. Fisheries Oceanography. Fishing News (Books) Ltd. London.

Jufri A, Amran MA, Zainuddin. 2014. Karakteristik Daerah Penangkapan Ikan Caka- lang Pada Musim Barat Di Perairan Teluk Bone. Jurnal IPTEKS PSP. 1(1): 1-10

Kurnia, Purnawan S, Rizwan T. 2016. Pemetaan Daerah Penangkapan Ikan Pelagis Kecil Di Perairan Utara Aceh. Universitas Syiah Kuala - Aceh. Jurnal IImiah Mahasiswa Kelautan Perikanan Unsyiah. 1(2): 185-194.

Kuswanto TD, Syamsuddin ML, Sunarto. 2017. Hubungan Suhu Permukaan Laut dan Klorofil-A Terhadap Hasil Tangkapan Ikan Tongkol Di Teluk Lampung. Universitas Padjadjaran - Bandung. Jurnal Perikanan dan Kelautan. 8(2): 90-102.

Laevastu T, Hela I. 1970. Fisheries Oceanography and Ecology. London : Fishing News Books Ltd.

Nurani TW, Murdaniel RPS, Harahap MH. 2013. Fresh Tuna Handling Quality For Tuna Longliner Caching For Export Market. Institut Pertanian Bogor - Bogor. Jurnal Marine Fisheries. 4(2): 153-162.

Pelabuhan Perikanan Samudera Lampulo. 2016. Rekapitulasi Ikan Yang Didaratkan DI UPTD Pelabuhan Perikanan Samudera Lampulo, Kota Banda Aceh Tahun 2016. Banda Aceh - Aceh. Dinas Kelautan dan Perikanan Provinsi Aceh.

Prastianto F. 2016. Analysis and Mapping of Chlorophyll-a Concentrations in the Makassar Stait as a Reference For Producing Local Fishing Forecast Map Using Aqua-MODIS Satellite Imagery. Universitas Mulawarman - Samarinda. Jurnal IImu Perikanan Tropis. 21(2): 024-031.

Prayoga IMS, Putra IDNN, Dirgayusa IGNP. 2017. Pengaruh Sebaran Konsentrasi Klorofil-a Berdasarkan Citra Satelit Terhadap Hasil Tangkapan Ikan Tongkol (Euthynnus sp) di Perairan Selat Bali. Universitas Udayana - Bali. Journal of Marine and Aquatic Sciences. 3(1): 3046.

Putra E, Gaol JL, Siregar VP. 2012. Relationship Chlorophyll-a Concentration And Sea Surface Temperature With Primary Pelagic Fish Cathes In Java Sea From Modis Satelite Images. Institut Pertanian Bogor - Bogor. Jurnal Teknologi Perikanan dan Kelauatan. 3(2): 1-10.

Putra II, Sukmono A, Wijaya AP. 2017. Analisis Sebaran Area Upwelling Menggunakan Parameter Suhu Permukaan Laut, Klorofil-a, Angin dan Arus Secara Temporal Tahun 2003 - 2016. Universitas Dipone- 
goro - Semarang. Jurnal Geodesi Universitas Diponegoro.

Rambun A, Sunarto, Nurruhwato I. 2016. Selektivitas Alat Tangkap Purse Seine di Pangkalan Pendaratan Ikan (PPI) Muara Angke Jakarta. Universitas Padjadjaran Bandung. Jurnal Perikanan Kelautan. 8(2): 97-102.

Sahidi S, Sapsuha GD, Ahmad FL, Laitupa, Tangke U. 2015. Hubungan Faktor Oseanografi Dengan Hasil Tangkapan Pelagis Besar Di Perairan Batang Dua Propins Maluku Utara. UMMU-Ternate. Jurnal Ilmiah agribisnis dan Perikanan (agrikan). 8(2).

Talib A. 2017. Tuna dan Cakalang (Suatu Tinjauan : Pengelolaan Potensi Sumberdaya di Perairan Indonesia. UMMU - Ternate. Jurnal IImiah agribisnis dan Perikanan (agrikan). 10(1).
Tangke $\mathrm{U}$, Karuwal $\mathrm{JCH}$, Zainuddin M, Mallawa A.2015. Effect of Sea Surface Temperature and Chlorophyll-a Distributions On Yellowfin Tuna (Thunnus albacares) Catch In The Waters of Southhern Halmahera Sea. Jurnal IPTEK PSP, 2(3):248-260.

Triarso I. 2012. Potensi dan Peluang Pengembangan Usaha Perikanan Tangkap di Pantura Jawa Tengah. Universitas Diponegoro - Semarang. Jurnal Saintek Perikanan. 8(1): 65-73.

Zainuddin M, Nelwan AFP, Farhum SA, Najamuddin MAI, Kurnia M. 2013. Characterizing Potential Fishing Zone of Skipjack Tuna during the Southeast Monsoon in the Bone Bay-Flores Sea Using Remotely Sensed Oceanographic Data. International Journal of Geosciences, 4: 259-266. 